\title{
The Uniqueness of English Noun Phrase In Relation to Word Order Universals
}

\author{
T.M.A. Kristianto \\ Sarjanawiyata Tamansiswa University
}

\begin{abstract}
The languages used all over the world have their own grammars consisting of certain components, like items, word order, and prosodic patterns. Based on the findings of the typological research conducted by some linguists, like Chomsky (1965), Greenberg (1966), and Hawkins (1983), it is known that the human languages have certain tendencies. After comparing a number of 30 languages, Greenberg made three classifications of language in terms of universal word order, they are; (1) the languages of VSO type, (2) languages of SVO type, and (3) languages of SOV type. He found that the three types of classification correlate with the languages in other places in the grammar consistently. In addition, he also made 15 formulations of universal word orders, in which three of them are: (1) Languages with dominant SVO order always have prepositions; (2) on the contrary, the ones with SOV type usually have postpositions; and (3) in the languages with dominant SVO order, the genitive and adjectives follow the noun. This formulation is supported by Hawkins after comparing 336 languages from different families.

Based on the above formulation; it is found shat English has uniqueness in terms of the phrase order. In this language, the order of NP is AN and GN despite having a relatively fixed order, SVO. This study aims to discuss the forms of English NP and to find out the reason why English has uniqueness in its phrase order based on the formulation made by Greenberg and Hawkins.
\end{abstract}

Key words: universal grammar, components of grammar, word order, typology 


\section{A. Introduction}

Language is a very important means of communication by which people . interact each others. They can communicate with the language by acquiring the rules of the language. In linguistics, the existing rules of certain language are called grammars. According to Poedjosoedarmo (2001: 9), the components of grammar. are items, word orders, and prosodic patterns. The items include words (lexicons), particles, and affixes. Word orders or syntactical orders refer to how words are arranged into phrases, and how the phrases are arranged to form sentences (Crystal, 1992: 98). In practice, the order goveming the arrangement of phrases is called $a$ word order, while the one governing the arrangement of sentences is called a phrase order. The prosodic patterns are supra-segmental phonemes including stress and intonation. These patterns may apply to the pronunciation of words and the intonation of sentences.

For years, many linguists spent their time to investigate the grammars of different languages in the world. Their studies are aimed at seeking universal grammars. Chomsky (1965), for example, conducted a deep analysis on English. He thought that by analyzing a language deeply, he could reveal the grammars of other languages. Then, Greenberg (1966).compared 30 languages from different typology. Based on his findings, he divided languages in the world into three types of universal word order, they are (1) Verb + Subject + Object (VSO), (2) Subject + Verb + Object (SVO), and (3) Subject + Object + Verb (SOV). Through the study, he found that the three types of phrase order correlate with word orders in other places in the grammar consequently. Finally, he formulated a number of 15 universal phrase orders; three of them are (1) Languages with dominant SVO order always have prepositions; (2) on the contrary, the ones with SOV type usually have postpositions; and (3) in the languages with dominant SVO order, the genitive and adjectives follow the noun (Hawkins, 1983: 19-20).

The research on language typology was then followed by other linguists, like Vennemann, Keenan, and Comrie (Hawkins, 1983: 19-20). Hawkins (1983), for example, investigated much more languages. In his study, he compared 336 languages from 30 different language families. Based on his findings, he made further formulation that is the classification of languages into 24 phrase orders; each includes the correlation of the word orders and the number of languages belonged to certain types (Hawkins, 1983: 288). The complete formulation is as follows: 


\begin{tabular}{|c|c|c|c|}
\hline 1. $\mathrm{V}-1 / \mathrm{Pr} / \mathrm{NG} / \mathrm{NA}$ & (38) & 13. SVO/Po/NG/NA & (0) \\
\hline 2. $\mathrm{V}-\mathrm{I} / \mathrm{PI} / \mathrm{NGI} / \mathrm{AN}$ & (13) & 14. SVO/Po/NG/AN & (0) \\
\hline 3. $\mathrm{V}-1 / \mathrm{Pr} / \mathrm{GN} / \mathrm{AN}$ & (1) & 15. SVO/Po/GN/AN & (12) \\
\hline 4. $\mathrm{V}-1 / \mathrm{Pr} / \mathrm{GN} / \mathrm{NA}$ & (0) & 16. SVO/Po/GN/NA & (13) \\
\hline 5. $\mathrm{V}-1 / \mathrm{Po} / \mathrm{NG} / \mathrm{NA}$ & $(0)$ & 17. SOV/Pr/NG/NA & (10) \\
\hline 6. $\mathrm{V}-1 / \mathrm{Po} / \mathrm{NG} / \mathrm{AN}$ & $(0)$ & 18. SOV/Pr/NG/AN & $(0)$ \\
\hline 7. $\mathrm{V}-1 / \mathrm{Po} / \mathrm{GN} / \mathrm{AN}$ & (I) & 19. SOV/Pr/GN/AN & (2) \\
\hline 8. V-I/Po/NG/NA & $(0)$ & 20. SOV/Pr/GN/NA & $\cdot(0)$ \\
\hline 9. $\mathrm{SVO} / \mathrm{Pr} / \mathrm{NG} / \mathrm{NA}$ & $(56)$ & 21. SOV/Po/NG/NA & (i1) \\
\hline 10. SVO/Pr/NG/AN & (17) & 22. SOV/Po/NG/AN & $(0)$ \\
\hline 11. SVO/Pr/GN/AN & (7) & 23. SOV/Po/GNIAN & (96) \\
\hline 12. SVO/Pr/GN/NA & (4) & 24. SOV/Po/GN/NA & (55) \\
\hline
\end{tabular}

Table 1

- Formulation of Phrase Orders Made by Hawkins (1983)

In the table above, $V-1$ is the verb that occurs in the beginning of a sentence or that precedes the noun. Pr is Preposition, Po is Postposition, $N$ is Noun, $G$ is Genitive, and $\boldsymbol{A}$ is Adjective. Meanwhile, $\boldsymbol{S}$ is Subject, $\boldsymbol{V}$ is Verb, and $\boldsymbol{O}$ is Object of $a$ sentence.

The formulation made by Hawkins strengthens his predecessor's, Greenberg, in term of using Pr and Po although there is a little difference in the order of NG and NA. In his formulation, Hawkins said that languages of SVO type tend to use Pr, genitive follows noun (NG), and adjective follows noun (NA). This tendency occurs in 56 languages. Meanwhile, languages of SOV type tend to use Po, noun follows genitive (GN), and noun follows adjective (AN), which occurs in 96 languages.

What have been revealed by those linguists shows us the fact that the gramimars of human languages are something universal. It means that the ways the language items are arranged to form phrases and sentences follow universal orders. In this sense, the findings do not result in an absolute universal which all human 
languages have but they reveal the regularity found in different languages. From this point of view, it can be said that typology is language classification based on a group of characteristics shared by different languages (Poedjosoedarmo, 2001:2).

In relation to the phrase order, Poedjosoedarmo (2006: 137) suggests that we regard $\mathrm{S}$ and $\mathrm{O}$ as having the category of noun $(\mathrm{N})$. In this way, we can differentiate the type of sentences easily as NVNN, VNNN, NNNV, and free phrase order In this. case, the three N's are Subject (S), Direct Object (DO), and Indirect Object (IO). Meanwhile, a free order happens when the distribution of the four phrases $(\mathrm{S}, \mathrm{V}$, $\mathrm{DO}, \mathrm{DO})$ is interchangeable.

Based on the phrase order, English is classified into an SVO type of language, or when using the word category, an English sentence is composed of NVNN. With reference to the Hawkins' list, this language uses preposition (Pr) and should normally have a noun phrase (NP) order NG and NA, as about 56 out of 109 observe the tendency. Despite the fact, the order of NP in modern English does not follow the tendency, in which the $\mathrm{N}$ follows $\mathrm{G}$ and the $\mathrm{A}$ follows $\mathrm{N}$. Why this happens? Is there something that influences this 'unique' order? This phenomenon is interesting to discuss for a better understanding of this language. Chiefly, this study aims to (1) discuss the structure of English NP, and (2) find out the reason why this language has a different word order in its NP's.

\section{B. Methods}

A study of a certain language may be aimed at analyzing a language at a single point in time that is classified into synchronic linguistic or knowing the development of a language over a number of years that is classified into historical or diachronic linguistics (Aitchison, 2003: 10). As this study aims to discuss the structure of English noun phrase and tries to reveal the reason why English has a different word order in the NP, this discussion will certainly involve both kinds of linguistics. Descriptive method is used to describe the current structures of the NP's and also the reason for applying different order for the relation of $\mathrm{G}, \mathrm{A}$ and $\mathrm{N}$. The second objective will obviously deal with the historical background of English in order to reveal the changes undergone by the language. 


\section{Findings}

The structure of English noun phrases primarily consists of a premodification, head (headword), and post-modification. The category used as the pre-modifiers includes, Article (Art), Demonstrative (Dem), Pronoun (Pron), Number (Num), Adjective (A), Genitive (G), Noun (N), and Adverb (Adv); the head or headword is Noun (N); while the post-modifiers include Relative Clause (Rel.), Prepositional Phrase (PP), $A d v$. and $A$.

The uniqueness of the word order of the English NP is highly influenced by the change in its phrase order. In Old English (OE), the phrase order is relatively free, in which $N$ can move around in the sentence. Even, the N's could occur consecutively or uninterrupted by $V$. Consequently, the language needs overt case markers. Since the word order has changed into fixed order, SVO, the markers are not a necessity anymore. So, the inflected forms of $\boldsymbol{A r t}, \boldsymbol{A}$, and $\boldsymbol{G}$ which were previously used to mark the roles of $N$ in the sentence had been simplified. The forms of $A r t$ are simplified into the (definite), and $a$, an (indefinite). Though the presence of $A r t$ is not used to mark the cases of the $N$, in modern English it is still needed to mark the beginning of an $N P$, such as in 'the greedy man', 'a soft pillow', and 'an ugly figure'. Then, because the $A r t$ is still needed in that function, the $A$ and $G$ remain in the current position, before $N$. Besides, the presence of $A r t, A$, and $G$ is still used as a strong stress to mark a new information in English.

\section{Discussion}

\section{1 Theories of Noun Phrase}

A noun phrase can be defined as a phrase that may occur within one single word or phrase with"a noun as a head, Despite the fact that a noun phrase may occur' in one single word, as said by Baker (1989: 113), and may not consist of the noun at all, as in the rich and the poor, the writer focuses the discussion only on the one that occurs in a phrase with a noun as a head. The reason is that he wants to find out the word orders or structures of NP.

In general, as has been stated previously, a noun phrase in English is composed potentially of three parts; a head, pre-modification, and postmodification. In this structure, the head of the noun phrase is obligatory or it is a minimal requirement for the occurrence of a noun phrase. The other two parts, a 
pre-modification and pot-modification are optional (Jackson, 1982: 66). According to Quirk, et al. (1978), the structure of a noun phrase can be simple or complex. The simple one may consist only of a single word or only the determiner (Det) and the head, while the complex one may have multiple modifiers.

\section{2 The Elements of Noun Phrase}

A Pre-modification is the element of a noun phrase that occurs before or precedes the head of the noun phrase. It consists of a number of word categories arranged in a specific order, they are a determiner (Det), adjective (A), and noun (N) modifier (Jackson, 1982: 67). The determiner (Det) includes articles (Art) ( $a$, an, the), demonstratives (Dem) (this, that, those), numbers (Num) (two, three, first, fourth), Quantifiers (Q) (some, much, a lot of), genitives (G) (his, her, John's). The five categories may occur in such phrases as a bat, the basket, two students, the third choice, some salt, and his bike. Then, the third pre-modification is A, such as small and young, as in a small gift and the young lady. The fourth is $\mathrm{V}$, which can be ed participle like provided or ing participle like walking. The verb forms may appear in phrases like the provided words and $a$ walking stick. While the last is $\mathbf{N}$ modifier, like bamboo and rubber that appear in such phrases as two bamboo baskets and this rubber factory. The nouns are used to modify the head noun, basket and factory. In this structure, the noun may occur as a complement or an attribute of the head noun, for example the mathematics students and wool scarf. Besides, the category of Adv may sometimes be used in this position, as appears in the above table and on outside window.

A post-modification is the element of a noun phrase that occurs after or follows the head of the noun phrase. It consists of a number of categories including a relative clause (Rel), prepositional phrase (PP), adverb phrase (Adv), apposition (Ap.), and adjective phrase (A). They occur as a complement or an adjunct. The first type is a clause. It occurs to complete the meaning or to give detailed information about and specify the head (as an adjunct) that may appear in a phrase like the book that I showed you yesterday. There, the Rel. that I showed you yesterday, refers to the noun book as the head of the NP. The second type is a PP. It always occurs as a post modifier of the NP that functions as a complement or an adjunct. As an example is the phrase the mangoes in the basket, in which the postmodifier in the basket functions as an adjunct. The third type is an Adv. It is used to give information about time or place, as in the week before and those examples 
above. In the two phrases, before is as adverb. of time and above is an adverb of place. The fourth is an Ap. It functions as an adjunct and always has the same meaning with the head, as in Laila, my girlfriend and Jakarta, the capital of Indonesia. In the two phrases, the Ap. my girlfriend and the capital of Indonesia function as the adjunct of each head. Finally, the last is an A. This type of post modifier is rarely used. It only appears with a Pron. as a head, like something interesting and somebody strange. In the two examples, the words interesting and strange modify its head, something and someone.

\section{D.3 The Structure of Noun Phrase}

As said by Quirk (1978: 857), just as the sentence may be indefinitely complex, so may the noun phrase. The structure of noun phrase can be simple or complex. The simple structure only consists of a Det. and a head, as in the store, in which Art the is the Det and $\mathbf{N}$ store is the head, while the complex one may consist of a Det., a pre-modifier, and a head, as in the new book store. In this phrase, Art the is the Det., $\mathbf{A}$ new and $\mathbf{N}$ book are pre-modifiers, while the head is the $\mathbf{N}$ store. A complex noun phrase may be composed of a Det., a head, and a postmodifier as in the store near my campus. Here, Art the is the Det., $\mathbf{N}$ store is the head, and PP near my campus is the post-modifier. Even, the more complex NP can be expanded with both pre-modifiers and post-modifiers, which result in the new book store near my campus which sells quality books and stationeries. This phrase consists of Art the as Det., $\mathbf{A}$ new and $\mathbf{N}$ book as pre-modifiers, $\mathbf{N}$ store as the head, PP near my campus and Rel. which sells quality books and stationeries.

To know the elements of NP's, linguists frequently apply a technique that is known as a constituent analysis. This device is helpful to show the elements that constitute the NP. A typical constituent analysis introduced by Radford is called -Radford's theory or'N-bar theory (Radford, 1988: 172). In this theory, all elements except the head are phrases. Therefore, a single word like new can be described as a phrase. Using this device, the elements of NP's (1) the hat, (2) my green trousers, (3) two leather jackets, (4) a day before his father died, and (4) the news about their affairs broadcast on $T V$, can be shown as follows. 
(1)

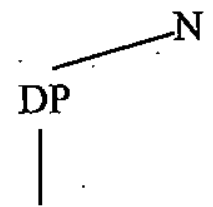

the
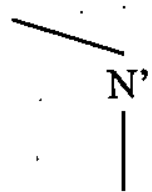

$\mathrm{N}$

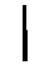

hat

(3)

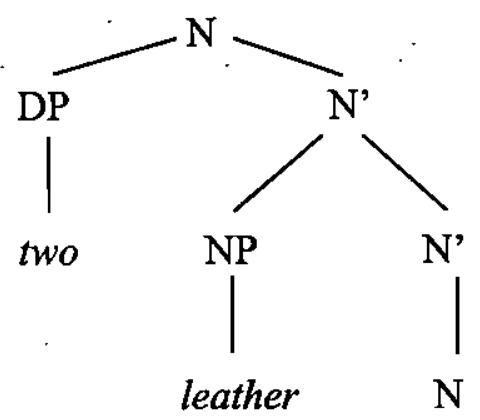

jackets
(2)

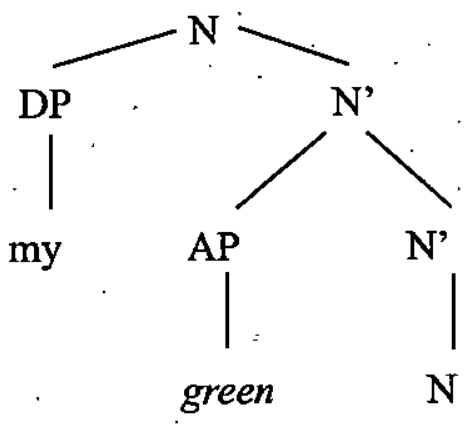

$\because$ trousers

(4)

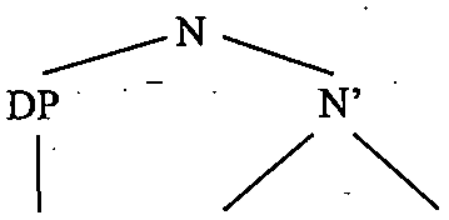

$a$
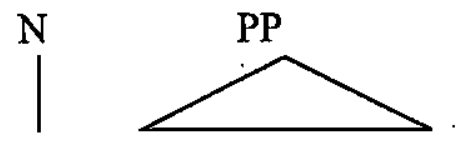

day before his father died

(5)

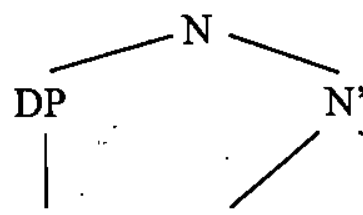

the
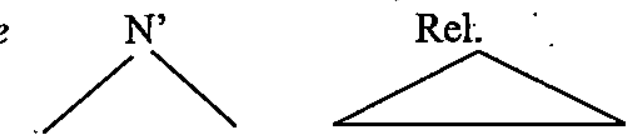

$\mathrm{N}$

$\mathrm{PP}$

broadcast on $T V$

news

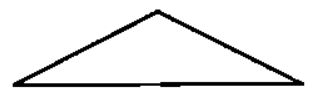

about their affairs 
Based on the theory of noun phrase illustrated by some examples above, the structure of English noun phrase can summarized in the following table.

\begin{tabular}{|c|l|c|l|}
\hline No. & \multicolumn{1}{|c|}{ Word Order } & No. & \multicolumn{1}{|c|}{ Word Order } \\
\hline 1 & Det.-N & 8 & Det.-N-PP \\
\hline 2 & Det. - A-N & 9 & Det.-N-Adv \\
\hline 3 & Det. - N-N & 10 & N-A \\
\hline 4 & Det. - V-N & 11 & N-Ap. \\
\hline 5 & Det. -Adv. -N & 12 & Det.-A/N-N-PP \\
\hline 6 & G-N/ Det. G-N & 13 & Det.-A/N-N-Rel. \\
\hline 7 & Det. -N-Rel. & 14 & Det.-A/N-N-PP-Rel. \\
\hline
\end{tabular}

Table 2

Word Order of English Noun Phrase

Based on the table above, it is obvious that in an English noun phrase, the noun follows the adjective (AN). In other words, the modifier (A) precedes the $\operatorname{modified}(\mathrm{N})$. To possession, likewise, the noun follows the genitive (GN).

The fact that the English noun phrase uses the order of $\mathbf{A N}$ and $\mathbf{G N}$ is different from the tendency of languages in the world formulated by Greenberg and Hawkins.

\section{D.4 The Development of English}

The earliest source of the English language was a prehistoric language that modern scholars call Proto-Indo-European (PIE). PIE was probably spoken about 5,000 years ago by people who lived in the region north of the Black Sea, in southeastern Europe. These people migrated through the centuries and gradually developed new languages (World Book, 2004).

According to the encyclopedia, one group of people who spoke PIE migrated west and divided into groups who spoke languages that were the ancestors of the Germanic, Greek, and Latin tongues. The Germanic languages developed into English, Danish, Dutch, German, Norwegian, and Swedish. The ancient Greek language became Modern Greek, and early Latin grew into French, Italian, and Spanish.

It is further said that the earliest known language in what is now Britain was spoken by a people called the Celts. The Romans started to conquer the Celts in 
A.D. 43 and ruled much of Britain until the early 400 's, when they returned to Rome. During the mid-400's, Germanic people who lived along the North Sea invaded Britain. The invaders belonged to three main tribes-the Angles, the Jutes, and the Saxons. All three tribes spoke their own Germanic dialect, but they probably understood one another. The Angles settled in central Britain. The word England came from a word meaning the Angle folk or land of the Angles, which was used by the late 800 's to refer to all the Anglo-Saxon people and their lands. The language of the Angles, Saxons, and Jutes became known as English (World Book, 2004, Smith, 1903: 1-2).

The history of English is conventionally divided into three main periods. The language of the first period, which began with the migration of certain Germanictribes from the continent to Britain in the fifth century (about.500 A.D.) and ended in the eleventh century (about 1100 A.D.), is called Old English. During the next period, from about 1100 to 1485 , the people spoke Middle English. The language of the period from about 1485 to the present is known as Modern English (http://www.m-w.com/help/faq/history.htm).

Old English was mainly a mixture of the Germanic languages of the Angles, Jutes, and Saxons. Old English resembles modern German more than it does modern English. The word order of Old English sentences is relatively free, similar to the word order in Modern German or Dutch (Alexander, 1962, cf. Poedjosedarmo, 2006: 138). German has richer inflectional morphology than English. Hawkins says that in general, all the grammatical distinctions that are drawn within English inflectional morphology are drawn in German as well, but not vice versa $(1986: 11)$.

In a free word order, N's or NP's may have different positions and may occur together consecutively. So, its occurrence can be NVNN, NNNV, VNNN, or NNVN. To mark the roles of each $\mathrm{N}$ in the sentence, a free order needs over case markers used to show whether a noun functions as Subject (S), Direct Object (DO), or Indirect Object (IO). When the role of $\mathrm{N}$ is as a Subject, it is in a Nominative case (Nom.), as a Direct Object is in Accusative case (Acc.), and as an Indirect Object is in Dative case (Dat.). In addition, the $\mathrm{N}$ can be in a Genitive case (Gen.) when it shows possession.

As an example of a language with a free order, German has a lot of inflections used as case markers. The inflections include Art (definite and 
indefinite), $\mathbf{A}$, and $\mathbf{N}$. For example, the forms of definite Art are der (Nom.), den (Acc.), des (Gen.), and dem (Dat.) for singular masculine, der (Nom.), die (Acc.), des (Gen.), and den (Dat.) for plural masculine. Meanwhile, the inflections of indefinite Art are ein (Nom.), einen (Acc.), eines (Gen.), einem (Dat.). Besides, the adjectives are also inflected, for example for the word gute ('good' in English) will be inflected as, gute (Nom.), guten (Acc.), guten (Gen.), and guten (Dat.) for singular masculine. While for plural masculine, the inflections are guten (Nom.), guten (Acc.), guten (Gen.), and guten (Dat.). So, with an adjective gute and a noun Vater ('father' in English), we can see the possible occurrences, like der gute Vater (Nom.), den guten Vater (Acc.), des guten Vaters (Gen.), and dem guten Vater (Dat.) for singular masculine, and die guten Väter (Nom.), die guten Väter (Acc.), des guten Väter (Gen.), and den guten Vätern (Dat.) for the plural form.

Old English (OE), as said to be more similar to Modern German, is also an inflected language. As of German, words like Dem., A, and $\mathbf{N}$ are also inflected to show their roles in the sentence, as a result of having a free word order.

\section{5 Demonstrative Adjectives}

In $\mathrm{OE}$, adjectives change their endings to show numbers, genders, and cases of the nouns they modify. Likewise, Dem, which are used to indicate spatial locations relative to the speaker (this, these, that, and those in ME) have certain inflections. The inflections are pes ('this' in ME) and se ('that' in ME) can be seen in the following tables.

\begin{tabular}{|l|l|l|l|l|}
\hline \multirow{2}{*}{\multicolumn{1}{|c|}{ Case }} & \multicolumn{3}{|c|}{ Singular } & Plural \\
\cline { 2 - 5 } & Masculine & Feminine & Neuter & All Genders \\
\hline Nominative & pes & pêos & bis & pâs \\
\hline Accusative & pisne & pâs & bis & pâs \\
\hline Genetive & pisses & pisse, piste & bisses & pissa, pisra \\
\hline Dative & pissum & pisse & bissum & pissum \\
\hline Instrument & pÿ & & büs & \\
\hline
\end{tabular}

Table 3

Inflections of Demonstrative Adjective pes ( Tony Jebson <jèbbo@atexas.net $>$ ) 


\begin{tabular}{|c|c|c|c|c|}
\hline & \multicolumn{3}{|c|}{ Singular } & Plural \\
\hline Case & Masculine & Feminine & Neuter & All Genders \\
\hline Nominative & sề & sêo, sîo & Fæt & pâ \\
\hline Accusative & pone & pâ & pat & pâ \\
\hline Genetive & pæs & $\mathrm{p}$ ?re & pæs & pâra, p?ra \\
\hline Dative & pầm & pâre & pâm, p ãm & pâm, pâm \\
\hline Instrument & pý, pon & býre & pý, pon & pâm \\
\hline
\end{tabular}

Table 4

Inflections of Demonstrative Adjective se ( Tony Jebson <jebbo@texas.net>)

Based on the two tables, it can be seen that both Dem. (pes 'this' and se 'that') change the forms according to the case, gender, and number. As they are A, they change their forms in order to agree with the gender of the noun being qualified.

In terms of $A r t$, the and $a / a n$, it is important to know that OE doesn't have a separate word for the definite Art the, so the Dem se in OE serves a dual purpose, as Dem that or definite $A \boldsymbol{r} t$ the (in ME). Moreover, in many places where today we would use the, OE omits it, so the phrase "feng to rice" -- a favorite of the AngloSaxon Chronicle -- translates as "succeded to the kingdom" (came to the throne). Even, the indefinite $\boldsymbol{A r t}$ is rarer than the definite one, and when it does appear is generally more definite than in ME. Often the indefinite Art is just omitted as in "on beorg" which translates as "onto a mountain", even though the word "a" is not there (Smith, 1896).

\section{D.6 Inflections 0f Pronouns}

In Modern English there are three recognizable different cases a word can have: the subjective case, the possessive case, and the objective case. To show the grammatical functions in a sentence, English pronouns, both $\mathrm{ME}$ and $\mathrm{OE}$, have certain inflections. They change their forms to show the cases or their roles in sentences. To show the difference, following is the inflections of personal pronouns for the first and the third person singular in $\mathrm{ME}$ and $\mathrm{OE}$ ( Tony Jebson <jebbo@texas.net>). 
MODERN ENGLISH CASE OLD ENGLISH

1st Person

Singular

2nd Person

singular

3rd Person.

\section{Singular}

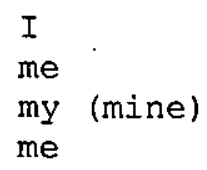

me

$\begin{array}{ll}\text { you } & \text { (thou) } \\ \text { you } & \text { (thee) } \\ \text { your } & \text { (thine) } \\ \text { you } & \text { (thee) }\end{array}$

he

him

his

him

she

her

her

her
Nominative
Accusative
Genitive
Dative.

Nominative

Accusative

Genitive

Dative

Nominative

Accusative

Genitive

Dative

Nominative

Accusative

Genitive

Dative ič
mě, meč
mîn
mě

pû

pě, peč

pîn

pĕ

hč

hine

his

him

hčo, hĩo

hîe, hî

hire

hire

Now, it can be observed clearly that pronouns in ME and OE inflect to show their grammatical functions in the sentence. Some of them have the same forms but some others are different. In-OE, there are some pronouns which have more than one form, they are me, pe, and heo.

\section{D.7.Inflections of Nouns}

In $\mathrm{OE}$, nouns possess what is called "gender". That is, a noun will be masculine, feminine, or neuter. $\mathbf{N}$ may change its case or number, but it will never change its gender. Gender is a feature which all nouns have by convention. So, there is nothing biologically feminine, masculine, or neuter about nouns which are grammatically feminine, masculine, or neuter. A pattern of endings which are added to the end of a noun to show its grammatical function is called a declension. Each noun in OE belongs to one declension. The most common ones are the masculine $a-$, neuter a-, feminine o-, weak masculine $-n$ and weak feminine - $n$ declensions. 
An illustration of noun declension in $\mathrm{OE}$ can be shown with a noun stan ("stone' in ME) which inflects through its different cases as follows:

\begin{tabular}{lllll} 
Singular & Old English & Plural & Old English & Translation in Modern English \\
\hline Nom. & stân & Nom. & stânas & stone/stones \\
Acc. & stân & Acc. & stânas & stone/stones \\
Gen. & stânes & Gen. & stâna & of the stone/stones \\
Dat. & stâne & Dat. & stânum & to/for the stone/stones
\end{tabular}

With different kinds of declension, following is the forms of noun in $\mathrm{OE}$.

\begin{tabular}{|l|c|c|c|c|}
\hline Singular & Neuter a- & Feminine 0- & Weak Masculine -n & Weak Feminine -n \\
\hline Approx. \% of nouns & $\mathbf{2 5}$ & $\mathbf{2 5}$ & $\mathbf{9}$ & $\mathbf{5}$ \\
\hline Nominative & scip "ship" & giefu "gift" & guma "man" & tunge "tongue" \\
\hline Accusative & scip & giefe & Guman & tungan \\
\hline Genitive & scipes & giefe & Guman & tungan \\
\hline Dative & scipe & giefe & Guman & tungan \\
\hline
\end{tabular}

Table 5

Singular Declensions of Noun (Tony Jebson <jebbo@texas.net>)

\begin{tabular}{|l|c|c|c|c|}
\hline Plural & Neuter a- & Feminine 0- & Weak Masculine -n & Weak Feminine -n \\
\hline Approx. \% of nouns & 25 & 25 & 9 & 5 \\
\hline Nominative & scipu & giefa & Guman & tungan \\
\hline Accusative & scipu & giefa & Guman & tungan \\
\hline Genitive & scipa & giefa & Gumena & tungena \\
\hline Dative & scipum & giefum & Gumum & tungum \\
\hline
\end{tabular}

Table 6

Plural Declensions of Noun ( Tony Jebson <jebbo@texas.net>) 


\section{8 Inflections of Adjective}

Most adjectives can be declined strong or weak. Whether the strong or weak form is used is not governed by the noun with which it is used. Instead, it is governed by how the $\mathbf{A}$ is used. There are three ways in which an $\mathbf{A}$ may be used; (1) it may stand alone -- for example "The man is old", (2) it may qualify an $\mathbf{N}$-- for example "The old man", and (3) it may follow a Dem or G - for example "My old friend" or "that old man". In the first two cases, the strong form of A is used. Only in the last case, when the A follows a Pron., is the weak form used.

Like $\mathbf{N}, \mathbf{A}$ also have a gender. The gender used for an $\mathbf{A}$ must agree (be the same as) with the gender of the $\mathbf{N}$ being qualified. The forms of weak adjectives follow those for tila "good", as shown in the table below:

\begin{tabular}{|l|c|c|c|c|}
\hline \multirow{2}{*}{\multicolumn{1}{|c|}{ Case }} & \multicolumn{3}{|c|}{ Singular } & Plural \\
\cline { 2 - 5 } & Masculine & Feminine & Neuter & All Genders \\
\hline Nominative & tila "good" & tile & tile & tilan \\
\hline Accusative & tilan & tilan & Tilan & tilan \\
\hline Genitive & tilan & tilan & Tilan & tilra, tilena \\
\hline Dative & tilan & tilan & Tilan & tilum \\
\hline
\end{tabular}

\section{Table 7}

Inflections of Weak Adjectives ( Tony Jebson <jebbo@texas.net>)

It can be seen that the inflectional endings are exactly as for weak nouns, with the addition of an alternative Genitive Plural ending -ra (generally tilena). Then, the inflectional endings of strong adjectives can be - observed in the following table: 


\begin{tabular}{|l|l|l|l|}
\hline Singular & Masculine a- & Neuter a- & Feminine o- \\
\hline Nominative & til "good" & til & tilu \\
\hline Accusative & tilane & til & Tile \\
\hline Genetive & tiles & tiles & Tilre \\
\hline Dative & tilum & tilum & Tilre \\
\hline
\end{tabular}

Table 8

Inflections of Singular Strong Adjectives ( Tony Jebson <jebbo@texas.net>)

\begin{tabular}{|l|l|l|l|}
\hline Plural & Masculine a- & Neuter a- & Feminine 0- \\
\hline Nominative & tile & tilu & tile, -a \\
\hline Accusative & tile & tilu & tile, -a \\
\hline Genetive & tilra & tilra & Tilra \\
\hline Dative & tilum & tilum & Tilum \\
\hline
\end{tabular}

Table 9

Inflections of Plural Strong Adjectives ( Tony Jebson <jebbo@texas.net> )

Learning the inflections of some word categories-Dem., Pron., $\mathrm{N}$, and A-we can make possible phrases, like pa fæger eagan ('those beautiful eyes'), his eald scip ('his old ship'), min 'micel cyning ('my great king'). In the form of sentences, it can be illustrated by four examples below:

(i) Se cyning frið nam.

The king peace made

('The king made peace')

.(ii) Waes se hungor on daes cyninges dagum on Egytum.

Was the hunger on the king's days in Egypt.

('There was a famine in the days of that king in Egypt') 
(iii) Se martyrhine geseah standan.

The martyr him saw stand.

('The martyr saw him standing')

(iv) He sade ðœt Norð̆manna land ware swyðe lang.

He said that Nortman land was very long.

('He said the land of Northman was very long')

(Poejọoedarmo, 2006: 139)

\section{D.9 Explaining the Uniqueness of the Word Order}

From the above description, it is quite clear now that the order of the NP in $\mathrm{OE}$ is different from that of $\mathrm{ME}$. In $\mathrm{OE}$, inflectional endings are needed as a consequence of having a free word order. In this order, the NP's should be compact, so they can move around in the sentence easily. The compactness of the NP is achieved by using inflectional endings which also function as linkers, so that the elements of the NP are closely related. As an example, observe the following phrases:

Old English

Segôda man

Fellagôdra manna

\section{Modern English}

The goodman

Manygoodmen

(Poedjosoedarmo, 2006: 145)

In the examples above, it can. be seen that suffixes $a$ and $r a$ function as linkers. Such linkers are not used anymore in ME as the phrase order has changed to a fixed order, SVO. In this order, compactness is not a necessity because the grammatical functions of the NP's can be seen from their positions in sentences.

In ME, the inflections of Dem (this, these, that, those) and Art (the, a, an) are not used to indicate cases and to make them agree with the genders of the nouns they modify anymore. The use of Dem is related to the number and spatial location relative to the speaker, while the use of $\mathbf{A r t}$ is related to the $\mathbf{N}$ being modified, 
definite or indefinite. In other words, the forms of Dem and Art (called determiners) ate not used as case markers because the function of an NP in the sentence is clear from its position.

Why is the order of AN and GN still maintained in ME noun phrase? The occurrence of the word order is based on some possibilities below:

1. As an inflected language, $\mathbf{O E}$ uses inflectional endings which serve as a dual purpose, that is to show case markers and to make the NP's compact as they should be easily moved around in sentences. The number of inflectional endings has been reduced in ME as the NP's are not required to be compact.

2. The occurrence of Art in $\mathrm{ME}$ is still used to indicate the beginning of a noun phrase, as in the green grass and a new road. Here, the adjective still precedes the noun it modifies because between the Art and A may not be inserted an $\mathbf{N}$, like *the grass green and *a road new. Perhaps, if the occurrence of Art is not needed anymore to show the beginning of an NP, the order may change from AN to NA as expected.

3. In $\mathrm{OE}$, the occurrence of $\mathbf{A}$ and $\mathbf{G}$ precede the $\mathbf{N}$ they modify because with their inflections, as linkers, they will make the NP compact. In ME their positions remain the same as in the high building, his strange experience, and John's funny pat because their occurrence, together with Art and Dem, are used to give a strong stress that is used to indicate new information. The order will probably change when new information is not necessarily shown with them.

Apart from the reasons above, there is an interesting phenomenon in which we can find some noun phrases in English showing a change in the order of NP. In the following phrases, the $\mathbf{A}$ and. $\mathbf{G}$ follow the head $\mathbf{N}$ as the expected tendency:

- 'water front'

- 'Attorney General'

- 'heir apparent'

- the dictionary of Tom

- the friend of mine

- the library of the school
- 'cityproper'.

- 'American original'

- 'Lords spiritual'

(Tom's dictionary)

(myfriend)

(the school's library) 


\section{E. Conclusion}

The structure of the English noun phrase consists of three elements: premodification, head, and post-modification. Pre-modification consists of Det. (the, an, my, two, some) and pre-modifiers consisting of certain categories (A, Adv., N), the head of a noun phrase is $\mathbf{N}$, while Post-modification consists of certain categories (Rel., PP, Adv, Ap., $\mathbf{A}$ ). In the word order of NP, it is seen that $\mathbf{N}$ follows $A$ and $\mathbf{G}$ or $\mathbf{A N}$ and $\mathbf{G N}$.

Based the Greenberg and Hawkin's formulation, the order of the English NP is unique. It is different from the tendency of the languages in the world with SVO type. The uniqueness is highly influenced by the historical background of English, which is the change from a free phrase order in OE to a fixed order, SVO, in ME. The change has resulted in the omission of case markers and the reduction of inflectional endings.

\section{Bibliography}

Aitchison, Jean. 2003. Linguistics. England: Cox \& Wyman Ltd.

Baker, L. C. 1989. English Syntax. England: The MIT Press.

Chrystal, David. 1992. The Cambridge Encyclopedia of Language. Cambridge: Cambridge University Press.

Comrie, Bernard. 1989. Language Universals and Linguistic Typology. Chicago: The University of Chicago Press.

Fromkin, Victoria and Robert Rodman.1988. An Introduction to Language. United States of America: Holt, Rinehard and Winston, Inc.

Hawkins, John A. 1983. Word Order Universals. London: Academic Press.

Hawkins, John A. 1986. A Comparative Typology of English and German Unifying the Contrasts. London and Sydney: Croom Helm Ltd.

- Jackson, Howard. 1982. Analyzing English. Oxford: Pergamon Press.

Poedjosoedarmo, S. 2000. "The Order of Noun Phrases and Syntax", Humanity: Journal of Humanity Studies. Vol.1. No.2. Surakarta: Language Center of Muhammadiyah University of Yogyakarta. 
Poedjosoedarmo, S. 2001. "Tèori Tata Bahasa Universal". Makalah dalam Seminar Regional Kedudukan dan Stmbangsih Teori Linguistik Prof. Dr. J.W.M. Verhaar, S.J., dalam Pengembangan Linguistik Indonesia, Yogyakarta: Fakultas Sastra USD

Poedjosoedarmo, S. 2006: "Perubahan Tata Bahasa: Penyebab, Proses dan Akibatnya". Makalah dalam Pidato Pengukuhan Jabatan Guru Besar Ilmu Linguistik pada Fakultas Sastra Universaitas Sanata Dharma Yogyakarta. Yogyakarta: USD.

Poedjosoedarmo, S. 2006: "Unique Elements in English Grammar", Phenomena: Journal of Language and Literature. Vol.9. No.3. Yogyakarta: Department of English Letters, Faculty of Letters, Sanata Dharma University.

Quirk, Randolph, Sidney Greenbaum, Geoffrey Leech, and Jan Svartvik. 1978. A Grammar of Contemporary English. London: Longman Group Limited.

Radford, Andrew. 1998. Transformational Grammar. Cambridge: Cambridge University Press.

Smith, Alphonso C. 1903. An Old English Grammar and Exercise Book. Boston: Allyn and Bacon. (Questia Media America, Inc. www.questia.com).

World Book 2004 Deluxe Edition. Chicago: World Book, Inc.

http:/www.m-w.com/help/faq/history.htm (retrieved on Monday, Nov. 12, 2007). http://www.questia.com/read/91195119 (retrieved on Monday, Noy. 12, 2007). (Tony Jebson<jebbo@texas.net>) (retrieved on Thursday, Nov.15, 2007). 